\title{
Probiotics Have the Potential to Significantly Mitigate the Environmental Impact of Freshwater Fish Farms
}

\author{
Cosmas Nathanailides ${ }^{1,2}, * \mathbb{D}$, Markos Kolygas ${ }^{3}$, Konstantina Choremi ${ }^{4}$, Theodoros Mavraganis ${ }^{1}$, \\ Evangelia Gouva ${ }^{3}$, Kosmas Vidalis ${ }^{4}$ and Fotini Athanassopoulou ${ }^{3}$ \\ 1 Department of Agriculture, University of Ioannina, GR 47100 Arta, Greece; theodore1978@gmail.com \\ 2 Institute of Environment and Sustainable Development (IESD), University Research Center of \\ Ioannina (URCI), GR 45110 Ioannina, Greece \\ 3 Laboratory of Pathology of Aquatic Animals, Ichthyology \& Aquaculture, Faculty of Veterinary Medicine, \\ University of Thessaly, GR 43100 Karditsa, Greece; kolygas@vet.uth.gr (M.K.); egouva@uoi.gr (E.G.); \\ eathan@vet.uth.gr (F.A.) \\ 4 Department of Animal Production, Fisheries \& Aquaculture, School of Agricultural Sciences, \\ University of Patras, GR 30200 Mesolonghi, Greece; ntinaxoremi@yahoo.gr (K.C.); kvidalis@upatras.gr (K.V.) \\ * Correspondence: nathan@uoi.gr
}

check for updates

Citation: Nathanailides, C.; Kolygas, M.; Choremi, K.; Mavraganis, T.; Gouva, E.; Vidalis, K.;

Athanassopoulou, F. Probiotics Have the Potential to Significantly Mitigate the Environmental Impact of Freshwater Fish Farms. Fishes 2021, 6 , 76. https://doi.org/10.3390/ fishes6040076

Academic Editor: Paula Enes

Received: 5 October 2021

Accepted: 1 December 2021

Published: 8 December 2021

Publisher's Note: MDPI stays neutral with regard to jurisdictional claims in published maps and institutional affiliations.

Copyright: (C) 2021 by the authors Licensee MDPI, Basel, Switzerland. This article is an open access article distributed under the terms and conditions of the Creative Commons Attribution (CC BY) license (https:// creativecommons.org/licenses/by/ $4.0 /)$
Abstract: Probiotics for freshwater fish farming can be administered as single or multiple mixtures The expected benefits of probiotics include disease prophylaxis, improved growth, and feed conversion parameters, such as the feed conversion rate (FCR) and specific growth rate (SGR). In the current work, we review the impact of probiotics on freshwater finfish aquaculture. Data were gathered from articles published during the last decade that examined the effects of probiotics on fish growth, FCR, and water quality in freshwater fishponds/tanks. While the expected benefits of probiotics are significant, the reviewed data indicate a range in the level of effects, with an average reduction in ammonia of $50.7 \%$, SGR increase of $17.1 \%$, and FCR decrease of $10.7 \%$. Despite the variability in the reported benefits, probiotics appear to offer a practical solution for sustainable freshwater aquaculture. Disease prophylaxis with probiotics can reduce the need for antibiotics and maintain gut health and feed conversion. Considering that fish feed and waste are two significant parameters of the aquaculture ecological footprint, it can be argued that probiotics can contribute to reducing the environmental impact of aquaculture. In this direction, it would be beneficial if more researchers incorporated water quality parameters in future aquaculture research and protocols to minimize aquaculture's environmental impact.

Keywords: aquaculture; probiotics; fish welfare

\section{Introduction}

According to the Food and Agriculture Organization/World Health Organization (FAO/WHO) definition, probiotics are 'live microorganisms that, when administered in adequate amounts, confer a health benefit on the host'. In aquatic environments, the concept of probiotics also includes microorganisms that exert a beneficial effect not only by colonizing the host but also by being present in the water [1]. Bacteria, yeast, and algae are extensively utilized as probiotics in aquaculture [2-14].

Aquaculture has a long history of using probiotics to enhance gut health and water quality. Probiotics for freshwater aquaculture may consist of a single strain or a range of microorganisms. Bacillus spp., lactic acid bacteria (LAB), such as Bacillus sp., Lactobacillus sp., Enterococcus sp., and yeast (Saccharomyces cerevisiae) diluted in the water or incorporated into fish feeds, and nitrifying/denitrifying bacteria, diluted in the water are often utilized as single or multiple probiotic mixtures in research and commercial formulations for freshwater fish farming [2-15].

The expected benefits include disease prophylaxis, prevention of disease spread, an improvement in food conversion efficiency (FCE), and an increase in the growth of farmed 
fish via the production of antioxidant enzymes, antioxidant activity, and promotion of healthy gut microbiota proliferation, all of which produce an enhancement in immunity and reduction in vulnerability to fish stress [2-15].

As a result, the potential benefits of probiotic treatment can be observed on the growth and efficiency of feeding and on the environmental parameters and aquaculture pollution. Probiotic management of diseases and prophylaxis, for example, can also reduce the need of antibiotics, one significant environmental issue of aquaculture. Likewise, environmental benefits of probiotics have been observed in experiments that monitored the water quality parameters of freshwater fishponds/tanks treated with probiotics diluted in the water or incorporated in the feed.

A lower feed conversion rate (FCR), for example, can be achieved when probiotics improve digestion by producing digestive enzymes, such as protease, amylase, and cellulase [16], and because of more efficient digestion, the organic load of fish farms may be reduced.

The potential benefits of probiotics on fish health also contribute to improvements in the growth, feed conversion efficiency, and water quality of freshwater fish species. Probiotics can modulate both local mucosal and systemic immune responses in farmed fish [16-18], thereby improving and maintaining fish health, preserving gut epithelial integrity, producing pathogen anti-virulence factors, and secreting antioxidant enzymes, resulting in a decrease in oxidative stress and cell damage, as well as a decrease in gut inflammation, in farmed fish $[13,15]$. B. probiotica has been used as a feed supplement and was demonstrated to result in an increase in the growth of a variety of fish species [6-8,10,12]. Additionally, Bacillus strains have been shown to benefit the environment by reducing ammonia levels and harmful algal blooms [19].

LABs are also frequently used in commercial preparations of aquaculture probiotics. Two enzymes in LAB cells, Mn-Kat (Mn-dependent pseudocatalase) and Heme-Kat, (Hemedependent catalase), can degrade hydrogen peroxide $\left(\mathrm{H}_{2} \mathrm{O}_{2}\right)$. LAB can also chelate iron to reduce $\mathrm{Fe}^{2+}$. Decreased $\mathrm{O}_{2}{ }^{-}$levels in $\mathrm{LAB}$ cells can also inhibit $\mathrm{Fe}^{2+}$ synthesis $[20,21]$. Other micronutrient factors and biochemical pathways, such as glutathione, thioredoxin, and vitamins $C$ and $E$, enhance the antioxidant capacity of LAB cells, thus contributing to redox homeostasis [20].

In summary, the effects of probiotics can be classified into two groups according to the aim of the treatment:

(a) Fish growth and welfare parameters, including effects on fish growth and feed conversion parameters, gut microbiota and anatomy, immunity, and resistance to pathogens.

(b) Environmental parameters, including fishponds and/or tanks (water quality, diversity of aquatic microbiota).

Farmed fish growth and welfare are critical for aquaculture sustainability today as there is a need to meet the requirements of the aquaculture industry for fish feed and exploration of new protein and lipid sources to replace fish meal and fish oil in fish feeds. This conversion is critical for the sector's growth as probiotics can assist in overcoming some issues with the digestibility and absorption of new diets, thus potentially reducing the reliance on fish meal and fish oil in fish feed manufacturing. Equally critical is water quality, which is a currently relevant issue. Competition for water resources from other sectors is expected to intensify, and a need to explore several avenues of research that could potentially improve the water quality of fish farms exists, thereby improving both the productivity of various aquaculture production methods via an increase in yield and improvement in water quality.

In the present work, we reviewed the effects of probiotics on freshwater finfish aquaculture, with a particular emphasis on growth, feed conversion, and water quality. The data were gathered from articles published over the last decade that investigated the beneficial effects of probiotics on freshwater fishponds and tanks. 


\section{Optimal Feeding Regimes and Improved Feed Conversion Are Prerequisites for Reducing the Environmental Impact Caused by Freshwater Fish Farms}

Sustainable development of freshwater (FW) aquaculture requires minimal environmental impact and monitoring of the organic load released in the aquatic ecosystem, while safeguarding fish welfare and the productivity of the sector.

Aquaculture of intensively cultivated fish uses intensive fish farming methods and is based mainly on fishponds with recirculating or openly flowing water. Environmental conditions, including water quality, stocking density, and temperature, can affect fish growth and the feed conversion efficiency (FCE) of farmed fish [22-26]. Furthermore, dietary regimes or pathological problems can compromise digestion and affect FCE [27-29]. Feed quality and quantity are crucial for fish welfare and growth. Little or no growth occurs if the fish do not consume the feed or are not capable of utilizing the feed due to a nutrient deficiency [24,30-32]. The optimal feeding of farmed fish necessitates an understanding of the digestion process, the digestive system, and the parameters that affect fish metabolism and why these parameters can influence feed conversion and the organic load generated by fish farms. Feed conversion varies significantly depending on the feed composition and management practices used in a fish farm [33]. The organic load and impact of freshwater fish farms in the aquatic ecosystem can be reduced by manipulation of the dietary regimes, for example, by adjusting the quantity of feed according to feed manufacturer feeding tables and by reducing the phosphorus content in the feed [24,29,32-35]. The feed conversion ratio (FCR) is the common measure that quantifies the efficiency by which fish convert feed with respect to weight increase. FCE measures how efficiently farmed fish convert fish feed to weight gain, whereas FCR represents the amount of fish feed required to gain one unit of weight. In practice, fish farmers may fail to follow the recommended feeding rations due to inadequate monitoring of size dispersion and total fish biomass, conditions that create uncertainty in the estimation of fish weight [35]. Furthermore, fish metabolism and feed consumption vary according to thermal conditions and several other parameters. Suboptimal temperatures and overfeeding can result in wasted feed and/or uneaten or poorly digested feed, all of which can result in an increase in FCR. For example, at low winter temperatures, farmed rainbow trout can exhibit a decrease in FCE, digestibility of dry matter, nitrogen levels, and energy derived from the diet, thus resulting in an increase in solid nitrogen waste output per $\mathrm{kg}$ of produced fish [24].

Figure 1 illustrates an example in which changes in FCR affect the release of phosphorus by fish farms. In this specific example, temperature affected the FCR of farmed rainbow trout fish farms, and increasing seasonal temperatures caused an increase in the appetite and feeding requirements of the fish. This process caused an increase in feed consumption but reduced the feed conversion efficiency (FCE), resulting in higher FCR that in turn affected phosphate levels. In fact, with a seasonal rise in temperature, a small increase (4.4\%) of FCR occurred whereas the levels of phosphate loading increased by $21.1 \%$ (calculated from Azevedo et al. [24]). The data reviewed in the present study indicate that the organic load in fishpond effluents may vary, which could be attributed to feeding control, for example, due to subjective or objective minor miscalculations for feeding requirements and fish biomass in addition to intestinal health issues. It is therefore reasonable to assume that a reduction in the organic load generated by trout farms could be achieved via more accurate estimation of fish biomass in each pond. Aquatic pollution is a significant environmental issue for freshwater ecosystems, affecting the ecological status of the benthos and the welfare fish in inland waters $[17,36]$. 


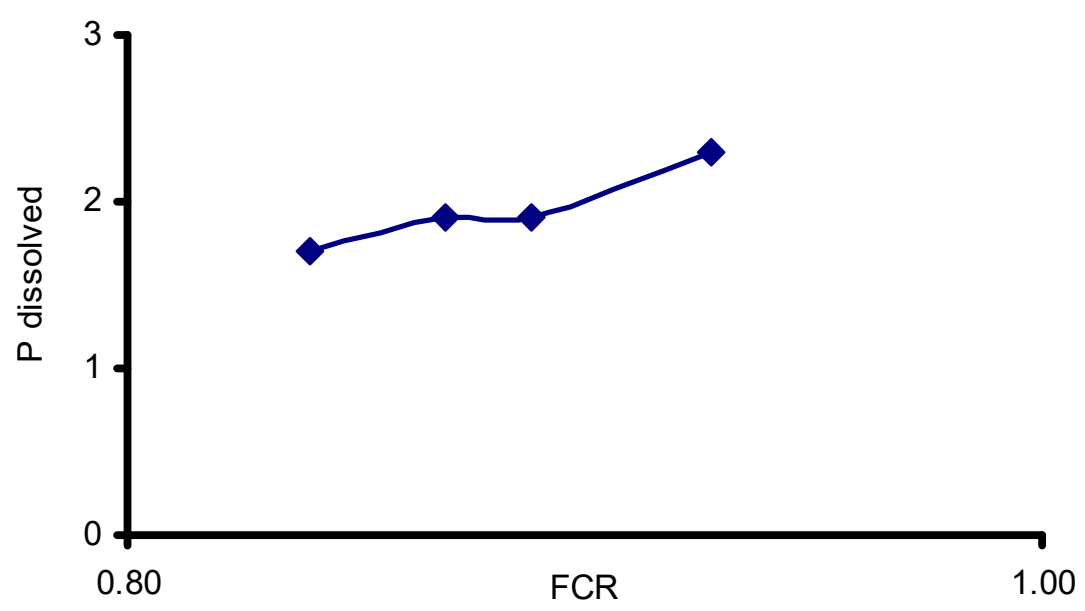

Figure 1. An example of how changes in the feed conversion ratio (FCR) due to temperature effects on the fish feeding rate and metabolism can affect the phosphorus load released by farmed rainbow trout. This change is due to an increase in FCR (such as when more feed is required to produce one $\mathrm{kg}$ of weight gain) that will result in a proportionally higher amount of phosphate released into the aquatic environment (data calculated from Azevedo et al. [24]).

\section{How Probiotics Can Improve FCR, Fish Health, and Fish Growth and Help Reduce} the Environmental Impact Caused by Freshwater Fish Farms

The expected benefits of probiotics on freshwater farmed fish are graphically illustrated in Figure 2. Probiotics can alter fish and water microbiota. Expected beneficial effects at the level of the aquatic ecosystem include improvement of the water quality in fish farm waters via control of the nitrification-denitrification process, resulting in reduced levels of ammonia and algal bloom. Expected beneficial effects of probiotics at the organism level are mainly related to the gut and include improvements in gut function, intestinal cellular integrity, inflammation control, pathogen inhibition, release of anti-virulence factors, protection from free radicals, and enhanced immunity. In other words, probiotics can improve fish health and growth feed conversion, and lead to a reduction in the organic load and antibiotics used in freshwater fish farms, thus reducing the environmental impact of aquaculture pollution.

3.1. Probiotics Can Improve the Digestion of Fish Diets and Support the Replacement of Fish Oils and Fish Proteins as Ingredients of Fish Feeds

A historical trend in this industry for accurately determining the protein requirements for each species, improve FCR, and lessen the environmental impact of aquaculture on aquatic ecosystems has been evolving. Several changes driven by research and global market forces in the composition of aquaculture feeds have been found. An obvious trend toward reducing the dependence of fish feed on fisheries and replacing fish protein and fish oils with alternative sources of proteins and fat has been found [37]. This trend reflects the response of the globally increasing aquaculture industry and the need to increase the production of aquaculture feed that requires wild caught fish as a major raw material, a basic ingredient that is characterized by a limited supply of overfished and regulated fish stocks. As a result, research on the formulation of new diets and the replacement of fish proteins with insect and plant proteins has intensified [27,38-41]. Probiotics can aid in the development of new fish feeds and lead to an improvement in gut health and feed conversion when used as supplements in conventional fish diets. Furthermore, probiotics can cause a reduction in the pathological issues occurring in the gut when alternative sources are used for the manufacture of fish feeds [20,27]. Likewise, gut function and immunity of beluga sturgeons fed a soya-bean-containing diet showed an improvement when experimental fish feed was supplemented with probiotics [42], illustrating the improvements that probiotics produce on fish health and growth, paving 
the way for the development of alternative fish feed, and therefore, reducing the reliance of the aquaculture fish feed industry on fisheries and fish meal [43,44].

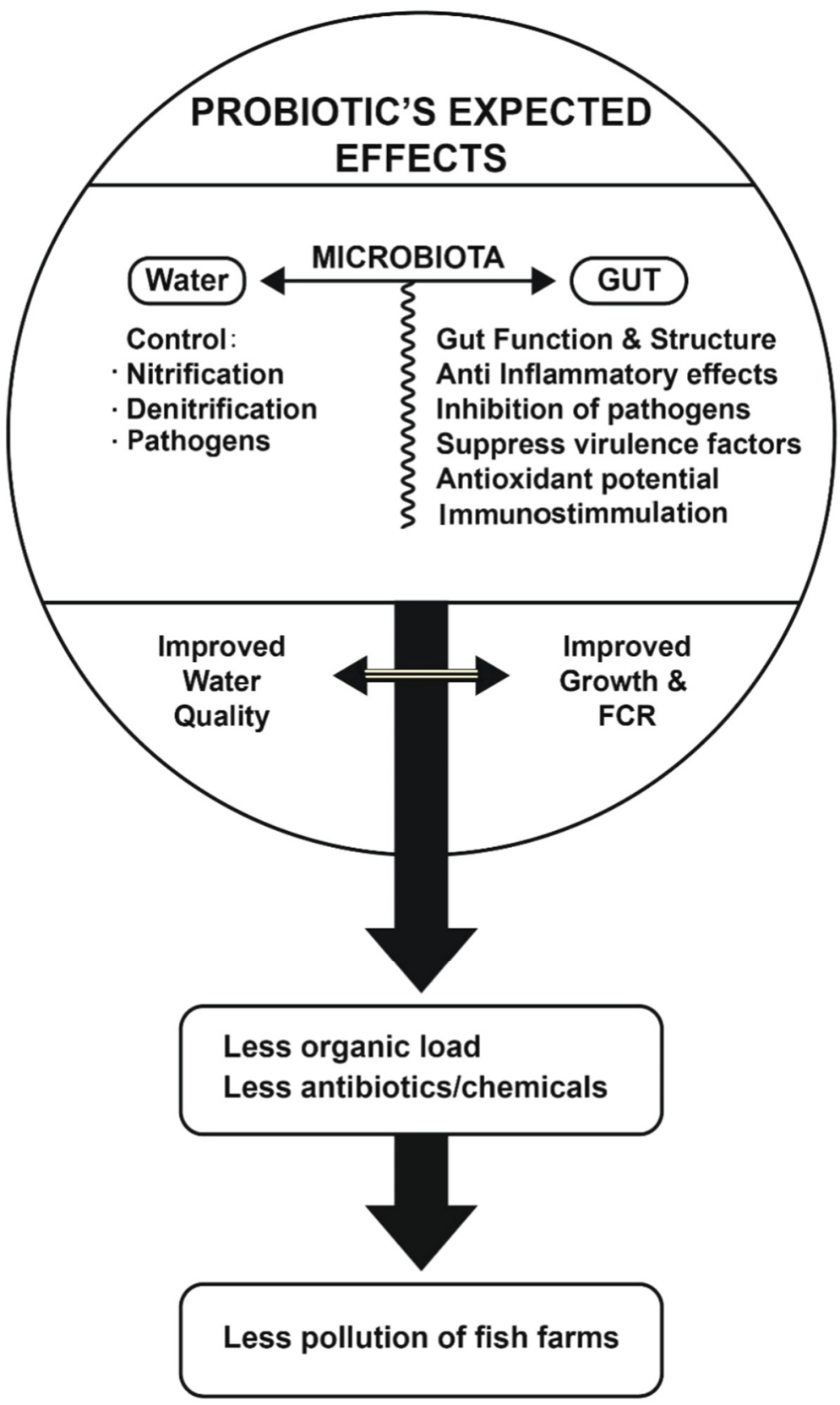

Figure 2. A flow diagram with the action of probiotics at the level of the aquatic ecosystem and at the organism level, resulting in improved fish health, feed conversion, and growth, and reduction of freshwater aquaculture pollution.

This potential benefit of probiotics on the development of diets with alternative protein sources coupled with extensive research on nutrition [2] in addition to the reduction of feed wastes [30] can lead to substantial economic and environmental improvements for the aquaculture sector. In any event, any new diet is expected to exhibit good performance in palatability, digestibility, and FCR, which will also be reflected in improved growth Environmental issues are also relevant, and this thinking can be seen in the composition of aquaculture feeds, which has changed significantly over the course of the last few decades, resulting in improved feed conversion and a reduction of nutrients released in the aquatic environmental by freshwater aquaculture [24,34]. 
A reduction or increase in feed conversion may reflect a corresponding increase or decrease of uneaten or poorly digested fish feeds. Open flow rainbow trout fish farms, for example, can generate a considerable amount of nutrients that are released in the aquatic ecosystems, which can vary with season, feeding regimes, and farming systems $[22,24,27]$.

The organic load generated by fish farms may vary according to unconsumed or poorly digested fish feed, fish metabolism, and excretion, all of which can result in the accumulation of suspended nutrients in the water bodies into which effluents are released [37,45]. Even within the ponds, waste solids can form sediments into which neither nitrogen $(\mathrm{N})$ nor phosphorus (P) will be deposited and will not support bacterial growth, thus affecting the levels of ammonium nitrogen $\left(\mathrm{NH}_{4}-\mathrm{N}\right)$, oxygen, and $\mathrm{P}$ in the water column of fishponds. These characteristics may have an impact on the water quality and growth of farmed fish in addition to a negative environmental impact $[45,46]$. Nutrients in the water column and pond sediment can increase according to the organic load released by fish farms, directly increasing the environmental impact of fish farms in the aquatic ecosystem [45-47]. Under such conditions, the organic load generated by fish farms will provide nutrients for bacteria, a process that can sometimes result in proliferation of fish pathogens [48].

Fresh water aquaculture can result in an increase in nutrient concentrations, and an increase in eutrophication levels can occur because of fish farms' operations. Microbial ecology can be affected by such changes in nutrients and therefore, aquatic ecosystems may exhibit significant changes at the level of the microbial community; some of these changes may be related to pathogens [48]. For instance, through nutrient competition, certain beneficial bacteria can prevent the growth of harmful algae. Probiotics added to aquaculture water can significantly improve fish growth and water quality in addition to reducing pathogen levels. In fact, an interaction between fish gut microbiota and the microbiota of the aquatic environment occurs. Probiotics added to the diet or diluted in the water of fish tanks/ponds may result in an increase in microbiota diversity, reduction in pathogens, and lower levels of ammonia $\left(\mathrm{NH}_{3}\right)$, nitrite, and nitrates in the fishpond or tank [49]. These findings provide theoretical support for the use of probiotics in aquaculture water quality management and for the welfare of farmed fish that are exposed to unfavorable water quality conditions and pathogens.

\subsection{Probiotics Can Reduce Subacute Intestinal Pathological Problems, Improve Feed Conversion, and Reduce Disease Outbreaks, Mortality, and Antibiotic Usage}

Optimal fish feeding, fish welfare, and reduction of the environmental impact of fish farms are crucial parameters for the economic viability and sustainability of the sector $[24,30,34,45]$. The health status and the efficiency of the FCE of farmed fish may vary according to management and production methods [50]. Successful aquaculture requires safeguarding of the health of growing fish and optimization of the feed conversion, thereby achieving better FCR, reducing the amount of feed required to produce farmed fish, reducing the environmental impact generated by fish feed production, and reducing aquaculture wastes generated by wasted or poorly digested feed [30].

Poor digestion can result from intestinal pathological problems [51]. Intestinal pathological problems resulting from experimental fish diets reflecting an obstacle in the replacement of fish proteins with alternative sources have frequently been reported $[27,28,38,41,51]$. Intestinal health is crucial for animal growth and the efficiency of animal feeds [52-54]. Intestinal pathological problems in farmed fish can be associated with the disruption of intestinal function and reduction in the efficiency of feed conversion [37]. Subacute intestinal pathological problems, such as sub-acute intestinal inflammation [54], can affect feed digestibility [52]. Intestinal pathological issues may affect normal intestinal functions and produce a higher intestinal pathological index score; the subsequent inflammation can therefore result in higher excretion of nutrients resulting from impaired digestion [52-54].

For example, partial supplementation of fish protein with plant protein can result in subacute pathological gut problems, an issue that was observed in experiments that aimed to partially replace fish proteins with plant proteins. This partial replacement resulted in sub-acute pathological gut problems, such as gut inflammation [27], reduction in the 
density of goblet cells, and reduction in the efficiency of feed conversion [52]. Likewise, gut inflammation may also be triggered by infections that compromise hormonal homeostasis, gut microflora [55], and functional intestinal integrity, factors that consequently further reduce the growth potential of farmed fish $[43,44]$. Based on the above features, it can be assumed that even subacute pathological problems of the fish intestine will impair digestion efficiency and consequently FCR.

In addition to the nutritional parameters of probiotics, their application can lead to a reduction in antibiotic usage in aquaculture as probiotics have the capability of modulating gut microbiota, thereby preventing gut inflammation and reducing the need for treatment of gut pathological problems [11,12,56-58].

Aquaculture is an increasingly important socio-economic area of development for many areas of the world. In recent years, more intensive farming methods with added antibiotics have been used to increase yield and ensure that fish stocks are healthy and disease-free. The environmental impact of these processes and the risk to human health from antibiotic-resistant microbes, however, has necessitated a revision in the regulations of these aquaculture environments. In addition to public health issues, the welfare of farmed fish is currently a crucial prerequisite for the sustainability of the sector. Gut health is one significant parameter for farmed fish welfare $[59,60]$. Gut health status and subacute gut pathological issues are current welfare issues that constitute a major obstacle for sustainable aquaculture development that are widely investigated by fish nutritionists working with several farmed fish species [60-63]. Research on improving feeding regimes and developing new feeds with optimal digestibility and metabolism [62-65] is a prerequisite for sustainable aquaculture growth. Probiotics can reduce subacute pathological gut problems that are frequently exhibited by farmed fish. For example, tilapia exhibited an increase in goblet cell density and other gut anatomical parameters when fed with a diet that was supplemented with the probiotic Brewer's yeast, S. cerevisiae. Furthermore, supplementation of feed with S. cerevisiae resulted in higher growth and better feed conversion, thus illustrating how probiotics can improve gut health, feed utilization, and fish growth [66].

Probiotics offer a more environmentally sustainable approach to fish feed stocks that facilitates an improvement in disease prevention while minimizing the impact on the surrounding ecological systems $[3,4,8]$. Dietary-administrated LAB, for example, is found in the mucosal epithelium of the gut and helps prevent pathogen proliferation [58-60]. Probiotics added to the ponds of farmed tilapia resulted in an improvement in growth and increase in the lactic acid bacterial count in the water and the intestinal tract and an improved immune response and resistance against Aeromonas hydrophila [67].

The physiological mechanisms of this protection against pathogens include competition between probiotics and pathogens on extracellular binding sites at the mucosal epithelium $[13,16,60,67]$, leading to alterations of the extracellular $\mathrm{pH}[68]$ and the production of molecules with antibiotic properties [69] that can prevent pathogen proliferation. Additionally, improved immune responses can be exhibited, for example, Clostridium butyricum caused an improvement in leukocyte phagocytic activity, resulting in an increase in resistance to vibriosis in farmed rainbow trout [70].

\subsection{Probiotics Can Improve Water Quality of Freshwater Fishponds and Help Reduce the Environmental Impact of Freshwater Fish Farms}

Probiotics can result in improved fish growth and water quality of freshwater fishponds/tanks $[5,8,25,48]$, resulting in a reduction of some environmental issues related to fish farm effluents. Probiotics are members of the healthy intestinal microbiota, and evidence to suggest a positive effect of probiotics in improving the digestion, health, and growth of farmed fish can be found. Microbial modulation by probiotics may also help improve host nutritional status, and the growth of farmed fish fed with probiotic supplements exhibited improved feed conversion, a significant parameter for the sustainability of aquaculture [6,9].

Probiotics can be administrated via different methods to improve the physiology, growth performance, and immune responses of many fish species [70-75]. For example, it 
has been shown that nutrients are absorbed more efficiently when the feed is supplemented with probiotics that provide significant benefits to the digestive processes for a variety of fish species $[8,15,76,77]$. Ensuring that probiotics can be used effectively and improve animal health without impacting the surrounding water quality is important, and the commercial viability of these options is critical. Improvements of feed efficiency is one key area for development as it can help to reduce production costs and create a more economically sustainable approach for probiotic use [14]. It has also been demonstrated that probiotics are efficient in organic matter transformation to carbon dioxide, thus helping to minimize the accumulation of dissolved and particulate organic carbon during the growing season. This process could ultimately improve local water quality by balancing the production of phytoplankton and eutrophication in these environments [78].

Some issues concerning administration of probiotics, including problems associated with early life stages of development and the immaturity of the digestive tract, have been identified with the use of fish feed. Supplementation of rearing water is currently the main method for ensuring probiotic distribution and is applicable for fishes of all ages, resulting in a higher level of incorporation of probiotic bacteria [68].

Probiotics can also aid the development and viability of early life stages, hence increasing hatchery productivity. For example, larvae of the shortfin silverside Chirostoma humboldtianum (Valenciennes, 1835), an endemic freshwater fish species in Mexico with aquaculture potential, exhibited an increase in growth and viability when fed probiotic strains of Bifidobacterium animalis subsp. lactis strain BB-12 and bio-encapsulated L. johnsonii [79]. Similarly, common carp larvae grew faster when a mixture of $B$. circulans and B. licheniformis $\left(1 \times 10^{3}\right.$ colony-forming units $[\mathrm{CFU}] \mathrm{mL}^{-1}$ ) was added to rearing tanks [79].

For early life stages of cultivated fish, an appropriate administration option may be to add probiotics directly to water containing animal larva and combine this mixture with the use of enriched live feed [78-80]. In addition to the beneficial digestive and health effects of probiotics as feed supplements [81,82], adding probiotics to fishpond water can also be beneficial, and these benefits may include improvements in water quality, which is a critical parameter for growth, feed conversion, and farmed fish welfare [83-86]. Fish excrete $\mathrm{NH}_{4}-\mathrm{N}$ and $\mathrm{N}$ compounds in fishponds, and denitrification bacteria can convert these compounds to nitrites and nitrates. Probiotic microorganisms have been shown to improve the quality of water in a variety of ways. Heterotrophic bacteria that require both organic and inorganic sources of carbon for growth play a critical role in the breakdown of organic matter and the generation of particulate food items from dissolved organics [83]. Some evidence can be found that suggests that probiotics in freshwater aquaculture ponds or tanks, including recirculated freshwater aquaculture systems, have the potential to reduce toxic levels of $\mathrm{NH}_{3}$ and $\mathrm{P}$ [6-8]. Environmental concerns about the amount of organic matter released in aquaculture effluents, combined with global warming and competition from other industries for limited water resources, may limit the availability of water for freshwater fish farms. Under these conditions, technological advances in water treatment, such as partial recirculating aquaculture systems, could pave the way for the future of sustainable freshwater aquaculture.

While probiotics may indeed provide a practical solution to the above-described issues, several roadblocks preventing widespread adoption of relevant methods in the aquaculture industry exist at present. Numerous published studies demonstrate that probiotics have a broad range of beneficial effects on the gut microbiota, growth, immunity of freshwater fish, and the aquatic environment. Table 1 presents 11 papers published during the last 10 years that have investigated the effects of probiotics on freshwater fish growth, feed conversion, and $\mathrm{NH}_{3}$ levels. Based on the data presented in Table 1, the average percentage changes in $\mathrm{NH}_{3}$, specific growth rate (SGR), and feed conversion rate (FCR) are presented in Figure 3 and describe the effects of probiotics on the water quality and growth of freshwater fin fish species. 
Table 1. Examples of papers $(n=11)$ reporting the effects of probiotics on growth and water quality parameters of cultivated freshwater fish species over the last 10 years.

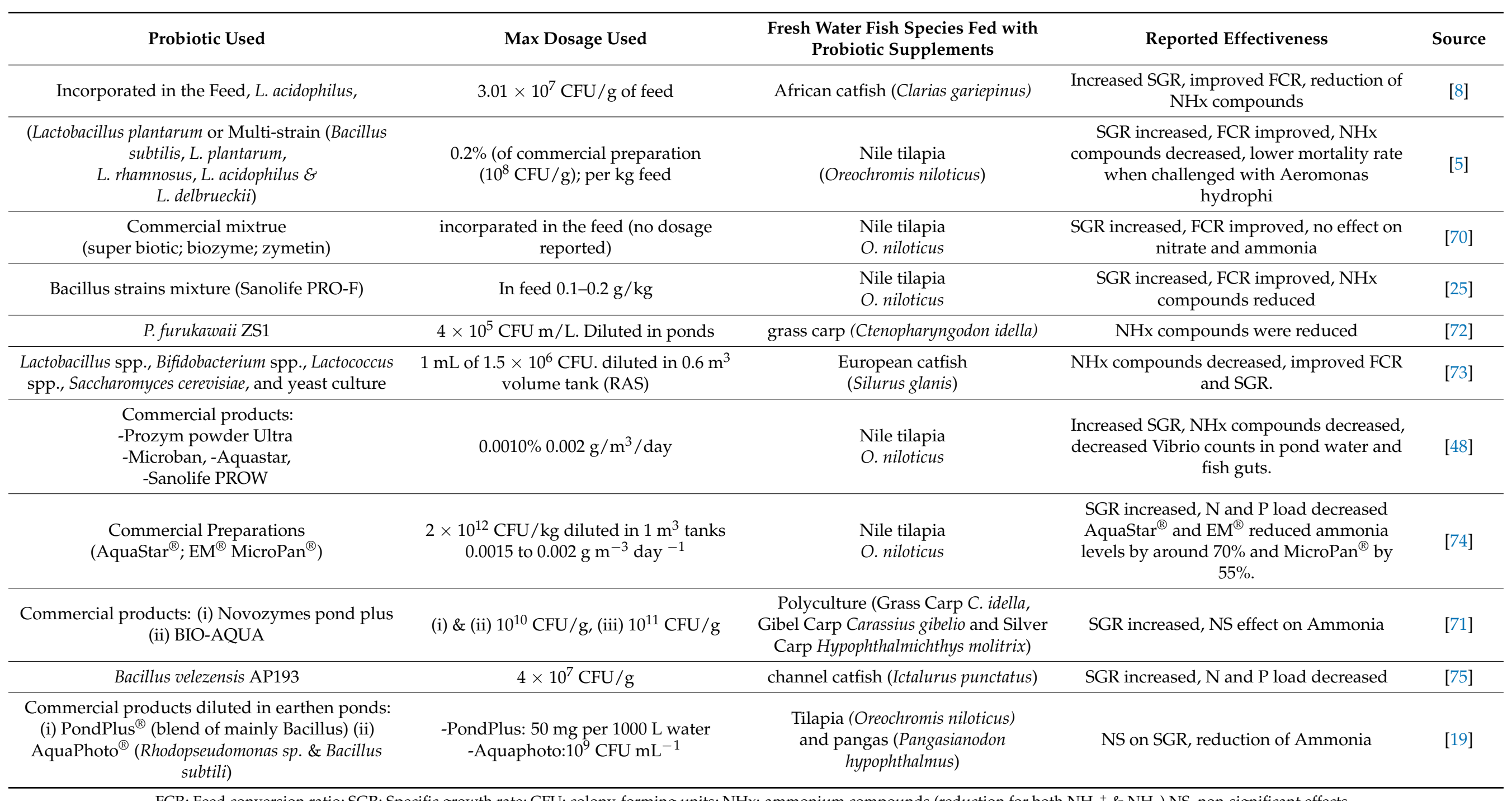

FCR: Feed conversion ratio; SGR: Specific growth rate; $\mathrm{CFU}$ : colony-forming units; $\mathrm{NHx}$ : ammonium compounds (reduction for both $\mathrm{NH}_{4}{ }^{+}$\& $\mathrm{NH}_{3}$ ) $\mathrm{NS}$, non-significant effects. 


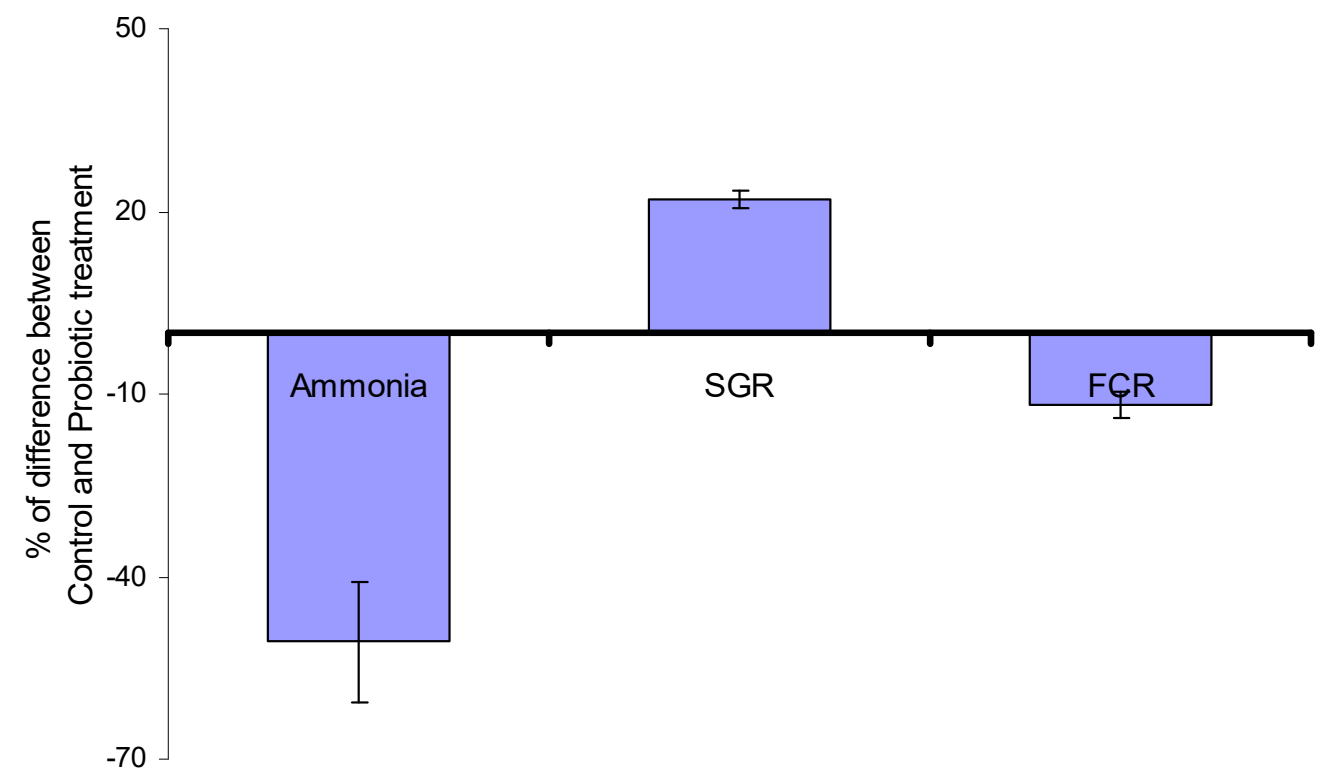

Figure 3. The average percentage change on ammonia $\left(\mathrm{NH}_{3}\right)$, specific growth rate (SGR), and feed conversion rate (FCR) as reported in peer-reviewed articles describing the effects of probiotics on water quality and growth of Figure 2. Reduction of ammonia $\left(\mathrm{NH}_{3}\right)$ was $50.75 \%$, growth rate was increased by $17.1 \%$, and the FCR was reduced by $10.7 \%$. Vertical bars indicate \pm standard deviation (sd) of the mean $(n=11)$.

A variety of reported effects on freshwater fish farms that vary in magnitude or in the absence or presence of significant effects have been published. Most of the results reviewed in this table are about Tilapia $[6,19,49,71,77,81]$ followed by catfish species $[9,76,85]$, carp species [82,84], and pangasius [19]. It should be emphasized that the data reviewed here refer to research results that investigated growth, $\mathrm{FCR}$, and $\mathrm{NH}_{4}$ levels in probiotic-treated fish.

Some studies have reported an improvement in all these parameters, while some reported no effects, and a wide range on the reported probiotics is reflected in the standard deviation (SD) of the changes presented in Figure 3. This variability in results, even when the same probiotic is used with the same fish species, has also been previously observed [14], indicating that the outcome of any probiotic treatment regardless of the method (supplementation in fish feed or dilution in water) is multidimensional and not always reproducible [69].

Despite the observed wide variability in the effectiveness of probiotics, the average reduction in $\mathrm{NH}_{3}$ was $50.7 \%$, SGR increased by $17.1 \%$, and FCR was decreased by $10.7 \%$ (corresponding to $107 \mathrm{~kg}$ less feed required for each ton of fish produced). Considering that feed and ammonia are two significant parameters of the ecological footprint of aquaculture, it can be argued that probiotics can have a significant effect on reducing the environmental impact of aquaculture. Indeed, the environmental benefits of probiotics on aquaculture can outweigh the environmental costs of probiotic production [87]; thus, probiotics can be recommended as a method for increasing aquaculture growth and reducing aquaculture pollution, thereby achieving operational and economic benefits.

The magnitude of the reported effects may vary according to several factors. Numerous variables interact to determine how probiotics affect fish growth, FCR, and water quality parameters. Even when these parameters are considered independently, they are known to be influenced by a plethora of intrinsic and extrinsic parameters. For instance, fish growth varies according to fish age and developmental stage. Environmental parameters are also critical; temperature is considered a controlling factor for fish metabolism. Nutritional parameters are also critical as optimal growth requires optimal feeding in terms of feed quality and quantity. Aquaculture methods and management are also critical, for example, feeding must be adjusted to the needs of farmed fish, water quality is crucial, 
and the needs of growing fish may vary according to age, body size, temperature, initial gut, water microbiota, and health parameters of individual fish. All these parameters are examples of how a variety of parameters can affect fish growth, fish feeding efficiency, responses, and effectiveness of probiotic treatments on fish health and growth.

\section{Conclusions}

In conclusion, the reviewed data indicate the potential for improving both the sustainability of freshwater fish farms and the health of farmed fish by investigating the potential benefits of using probiotics to achieve optimal feed utilization via improved digestion, feed conversion, and fish health. It can be concluded that several reasons to drive research and development towards improving FCR exist. This impetus derives from economics, fish welfare, and environmental concerns within the aquaculture industry. Several parameters can affect FCR and the environmental impact of freshwater fish farms, for example, affecting the levels of $P$ pollution and the organic load of wasted or poorly digested feed. Improved feeding regimes and probiotics are expected to have a significant impact on the economics of fish farms and the welfare of farmed fish in addition to digestion efficiency and the environmental impact of freshwater fish farms. In this direction, it would be beneficial for more researchers to include water quality parameters in future research in this field. This inclusion will allow for the development of probiotic treatment protocols that will aid aquaculture in minimizing its environmental impact.

Author Contributions: Conceptualization, C.N. and M.K.; methodology, C.N., M.K. and K.C.; software, T.M.; validation, K.C., K.V. and E.G.; formal analysis, M.K.; investigation, M.K., K.C., K.V. and F.A.; resources, C.N. and F.A.; data curation, M.K. and T.M.; writing-original draft preparation, C.N. and M.K.; writing-review and editing, K.V., E.G. and F.A.; visualization, C.N., M.K. and E.G.; supervision, C.N.; project administration, M.K.; funding acquisition, C.N. All authors have read and agreed to the published version of the manuscript.

Funding: This research received no external funding.

Acknowledgments: We thank two anonymous reviewers and the academic editors of Fishes (Section Environment and Climate Change) for their helpful comments and suggestions that greatly improved an earlier version of this manuscript.

Conflicts of Interest: The authors declare no conflict of interest.

\section{References}

1. Hill, C.; Guarner, F.; Reid, G.; Gibson, G.R.; Merenstein, D.J.; Pot, B.; Morelli, L.; Canani, R.B.; Flint, H.J.; Salminen, S.; et al. Expert Consensus Document: The International Scientific Association for Probiotics and Prebiotics consensus statement on the scope and appropriate use of the term probiotic. Nat. Rev. Gastroenterol. Hepatol. 2014, 11, 506-514. [CrossRef] [PubMed]

2. Bockus, A.B.; Rawles, S.D.; Sealey, W.M.; Conley, Z.B.; Gaylord, T.G. Effects of elevated temperature and dietary additives Thermal Care ${ }^{\mathrm{TM}}$, Bio-Mos ${ }^{\circledR}$, and GroBiotic ${ }^{\circledR}$ A on rainbow trout (Oncorhynchus mykiss) performance. Aquaculture 2021, $544,737084$. [CrossRef]

3. Soltani, M.; Ghosh, K.; Hoseinifar, S.H.; Kumar, V.; Lymbery, A.; Roy, S.; Ringø, E. Genusbacillus, promising probiotics in aquaculture: Aquatic animal origin, bio-active components, bioremediation and efficacy in fish and shellfish. Rev. Fish. Sci. Aquac. 2019, 27, 331-379. [CrossRef]

4. Paray, B.A.; El-Basuini, M.F.; Alagawany, M.; Albeshr, M.F.; Farah, M.A.; Dawood, M.A.O. Yucca schidigera Usage for Healthy Aquatic Animals: Potential Roles for Sustainability. Animals 2021, 11, 93. [CrossRef] [PubMed]

5. Hassani, M.H.S.; Jourdehi, A.Y.; Zelti, A.H.; Masouleh, A.S.; Lakani, F.B. Effects of commercial superzist probiotic on growth performance and hematological and immune indices in fingerlings Acipenser baerii. Aquac. Int. 2020, 28, 377-387. [CrossRef]

6. Mohammadi, G.; Rafiee, G.; Tavabe, K.R.; Abdel-Latif, H.M.; Dawood, M.A. The enrichment of diet with beneficial bacteria (single-or multi-strain) in biofloc system enhanced the water quality, growth performance, immune responses, and disease resistance of Nile tilapia (Oreochromis niloticus). Aquaculture 2021, 539, 736640. [CrossRef]

7. Mohammadi, G.; Adorian, T.J.; Rafiee, G. Beneficial effects of Bacillus subtilis on water quality, growth, immune responses, endotoxemia and protection against lipopolysaccharide-induced damages in Oreochromis niloticus under biofloc technology system. Aquac. Nutr. 2020, 26, 1476-1492. [CrossRef]

8. Putra, A.N.; Mustahal, M.; Syamsunarno, M.B.; Hermawan, D.; Fatimah, D.G.; Putri, P.B.; Sevia, S.; Isnaeni, R.; Herjayanto, M. Dietary Bacillus NP5 supplement impacts on growth, nutrient digestibility, immune response, and resistance to Aeromonas hydrophila infection of African catfish, Clarias gariepinus. Biodiversitas J. Biol. Divers. 2021, 22, 253-261. [CrossRef] 
9. Al-Dohail, M.A.; Hashim, R.; Aliyu-Paiko, M. Effects of the probiotic, Lactobacillus acidophilus, on the growth performance, haematology parameters and immunoglobulin concentration in African Catfish (Clarias gariepinus, Burchell 1822) fingerling. Aquac. Res. 2009, 40, 1642-1652. [CrossRef]

10. Van Doan, H.; Lumsangkul, C.; Hoseinifar, S.H.; Tongsiri, S.; Chitmanat, C.; Musthafa, M.S.; El-Haroun, E.; Ringo, E. Modulation of growth, innate immunity, and disease resistance of Nile tilapia (Oreochromis niloticus) culture under biofloc system by supplementing pineapple peel powder and Lactobacillus plantarum. Fish Shellfish. Immunol. 2021, 115, 212-220. [CrossRef]

11. Yanbo, W.; Zirong, X. Effect of probiotics for common carp (Cyprinus carpio) based on growth performance and digestive enzyme activities. Anim. Feed. Sci. Technol. 2006, 127, 283-292. [CrossRef]

12. Modanloo, M.; Soltanian, S.; Akhlaghi, M.; Hoseinifar, S.H. The effects of single or combined administration of galactooligosaccharide and Pediococcus acidilactici on cutaneous mucus immune parameters, humoral immune responses and immune related genes expression in common carp (Cyprinus carpio) fingerlings. Fish Shellfish. Immunol. 2017, 70, 391-397. [CrossRef] [PubMed]

13. Merrifield, D.L.; Carnevali, O. Probiotic modulation of the gut microbiota of fish. In Aquaculture Nutrition: Gut Health, Probiotics and Prebiotics; Wiley: Hoboken, NJ, USA, 2014; pp. 185-222.

14. Sugimura, Y.; Hagi, T.; Hoshino, T. Correlation between in vitro mucus adhesion and the in vivo colonization ability of lactic acid bacteria: Screening of new candidate carp probiotics. Biosci. Biotechnol. Biochem. 2011, 75, 511-515. [CrossRef] [PubMed]

15. Merrifield, D.; Bradley, G.; Baker, R.; Davies, S. Probiotic applications for rainbow trout (Oncorhynchus mykiss Walbaum) II. Effects on growth performance, feed utilization, intestinal microbiota and related health criteria postantibiotic treatment. Aquac. Nutr. 2010, 16, 496-503. [CrossRef]

16. Hai, N.V. The use of probiotics in aquaculture. J. Appl. Microbiol. 2015, 119, 917-935. [CrossRef] [PubMed]

17. Melo-Bolívar, J.F.; Pardo, R.Y.R.; Hume, M.E.; Díaz, L.M.V. Multistrain probiotics use in main commercially cultured freshwater fish: A systematic review of evidence. Rev. Aquac. 2021, 13, 1758-1780. [CrossRef]

18. Verschuere, L.; Rombaut, G.; Sorgeloos, P.; Verstraete, W. Probiotic Bacteria as Biological Control Agents in Aquaculture. Microbiol. Mol. Biol. Rev. 2000, 64, 655-671. [CrossRef]

19. Mahmud, S.; Ali, M.L.; Alam, M.A.; Rahman, M.M.; Jørgensen, N.O. Effect of probiotic and sand filtration treatments on water quality and growth of tilapia (Oreochromis niloticus) and pangas (Pangasianodon hypophthalmus) in earthen ponds of southern Bangladesh. J. Appl. Aquac. 2016, 28, 199-212. [CrossRef]

20. Langlois, L.; Akhtar, N.; Tam, K.C.; Dixon, B.; Reid, G. Fishing for the right probiotic: Host-microbe interactions at the interface of effective aquaculture strategies. FEMS Microbiol. Rev. 2021, 45, fuab030. [CrossRef]

21. Feng, T.; Wang, J. Oxidative stress tolerance and antioxidant capacity of lactic acid bacteria as probiotic: A systematic review. Gut Microbes 2020, 12, 1801944. [CrossRef]

22. Mavraganis, T.; Thorarensen, H.; Tsoumani, M.; Nathanailides, C. On the Environmental Impact of Freshwater Fish Farms in Greece and in Iceland. Annu. Res. Rev. Biol. 2017, 13, 1-7. [CrossRef]

23. Imsland, A.K.D.; Gunnarsson, S.; Thorarensen, H. Impact of environmental factors on the growth and maturation of farmed Arctic charr. Rev. Aquac. 2020, 12, 1689-1707. [CrossRef]

24. Azevedo, P.A.; Cho, C.Y.; Leeson, S.; Bureau, D.P. Effects of feeding level and water temperature on growth, nutrient and energy utilization and waste outputs of rainbow trout (Oncorhynchus mykiss). Aquat. Living Resour. 1998, 11, 227-238. [CrossRef]

25. Brett, J. Environmental factors and growth. In Fish Physiology; Hoar, W.S., Randall, D.J., Brett, J.R., Eds.; Academic Press: New York, NY, USA, 1979; Volume 8, pp. 599-675.

26. Myrick, C.; Cech, J.J. Temperature influences on California rainbow trout physiological performance. Fish Physiol. Biochem. 2000, 22, 245-254. [CrossRef]

27. Penn, M.H.; Bendiksen, E.; Campbell, P.; Krogdahl, Å. High level of dietary pea protein concentrate induces enteropathy in Atlantic salmon (Salmo salar L.). Aquaculture 2011, 310, 267-273. [CrossRef]

28. Kumar, V.; Fawole, F.J.; Romano, N.; Hossain, S.; Labh, S.N.; Overturf, K.; Small, B.C. Insect (black soldier fly, Hermetia illucens) meal supplementation prevents the soybean meal-induced intestinal enteritis in rainbow trout and health benefits of using insect oil. Fish Shellfish. Immunol. 2021, 109, 116-124. [CrossRef] [PubMed]

29. Thorpe, J.E.; Cho, C.Y. Minimising waste through bioenergetically and behaviourally based feeding strategies. Water Sci. Technol. 1995, 31, 29-40. [CrossRef]

30. Bureau, D.P.; Hua, K. Towards effective nutritional management of waste outputs in aquaculture, with particular reference to salmonid aquaculture operations. Aquac. Res. 2010, 41, 777-792. [CrossRef]

31. Lambert, Y.; Dutil, J.-D. Food intake and growth of adult Atlantic cod (Gadus morhua L.) reared under different conditions of stocking density, feeding frequency and size-grading. Aquaculture 2001, 192, 233-247. [CrossRef]

32. Cho, C.Y.; Bureau, D.P. Reduction of waste output from salmonid aquaculture through feeds and feeding. Prog. Fish Cult. 1997, 59, 155-160. [CrossRef]

33. Aguado-Giménez, F. Effect of Feed Delivery Rate and Pellet Size on Rearing Performance, Feed Wastage and Economic Profitability in Gilthead Seabream (Sparus aurata) Ongrowing. Water 2020, 12, 954. [CrossRef]

34. Berillis, P.; Mente, E. Histology of Goblet Cells in the Intestine of the Rainbow Trout Can Lead to Improvement of the Feeding Management. J. Fish. 2017, 11, 32-33. [CrossRef] 
35. Mavraganis, T.; Tsoumani, M.; Kolygas, M.; Chatziefstathiou, M.; Nathanailides, C. Using seasonal variability of water quality parameters to assess the risk of aquatic pollution from rainbow trout fish farms in Greece. Int. J. Energy Water Resour. 2021, 5, 379-389. [CrossRef]

36. Rafiee, G.; Saad, C.R. Nutrient cycle and sludge production during different stages of red tilapia (Oreochromis sp.) growth in a recirculating aquaculture system. Aquaculture 2005, 244, 109-118. [CrossRef]

37. Mavraganis, T.; Constantina, C.; Kolygas, M.; Vidalis, K.; Nathanailides, C. Environmental issues of aquaculture development. Egypt. J. Aquat. Biol. Fish. 2020, 24, 441-450. [CrossRef]

38. Burrells, C.; Williams, P.D.; Southgate, P.J.; Crampton, V.O. Immunological, physiological and pathological responses of rainbow trout (Oncorhynchus mykiss) to increasing dietary concentrations of soybean proteins. Veter. Immunol. Immunopathol. 1999, 72 , 277-288. [CrossRef]

39. Mente, E.; Carter, C.; Barnes, R.; Vlahos, N.; Nengas, I. Post-Prandial Amino Acid Changes in Gilthead Sea Bream. Animals 2021, 11, 1889. [CrossRef] [PubMed]

40. Ayala, M.D.; Galián, C.; Fernández, V.; Chaves-Pozo, E.; García de la Serrana, D.; Sáez, M.I.; Arizcun, M. Influence of low dietary inclusion of the microalga Nannochloropsis gaditana (Lubián 1982) on performance, fish morphology, and muscle growth in juvenile gilthead seabream (Sparus aurata). Animals 2020, 10, 2270. [CrossRef]

41. Mousavi, S.; Zahedinezhad, S.; Loh, J.Y. A review on insect meals in aquaculture: The immunomodulatory and physiological effects. Int. Aquat. Res. 2020, 12, 100-115.

42. Montazeri Parchikolaei, H.; Abedian Kenari, A.; Esmaeili, M. Soya bean-based diets plus probiotics improve the profile of fatty acids, digestibility, intestinal microflora, growth performance and the innate immunity of beluga (Huso huso). Aquac. Res. 2021, 52, 152-166. [CrossRef]

43. Dawood, M. Nutritional immunity of fish intestines: Important insights for sustainable aquaculture. Rev. Aquac. 2021, 13, 642-663. [CrossRef]

44. Ogunkalu, O. Effects of Feed Additives in Fish Feed for Improvement of Aquaculture. Eurasian J. Food Sci. Technol. 2019, 3, 49-57.

45. Tahar, A.; Kennedy, A.; Fitzgerald, R.D.; Clifford, E.; Rowan, N. Full Water Quality Monitoring of a Traditional Flow-through Rainbow Trout Farm. Fishes 2018, 3, 28. [CrossRef]

46. Carr, O.; Goulder, R. Fish-farm effluents in rivers-I. effects on bacterial populations and alkaline phosphatase activity. Water Res. 1990, 24, 631-638. [CrossRef]

47. Nathanailides, C.; Tsoumani, M.; Kakali, F.; Logothetis, P.; Beza, P.; Mayraganis, T.; Kanlis, G.; Delis, G.; Tiligadas, I.; Chatziefstathiou, M. A correlation between alkaline phosphatase and phosphate levels with the biomass of trout farm effluents. In Proceedings of the VI International Conference WATER \& FISH, Faculty of Agriculture, Zemun, Serbia, 12-14 June 2015; pp. 170-175.

48. Rurangwa, E.; Verdegem, M. Microorganisms in recirculating aquaculture systems and their management. Rev. Aquac. 2015, 7, 117-130. [CrossRef]

49. Kord, M.I.; Maulu, S.; Srour, T.M.; Omar, E.A.; Farag, A.A.; Nour, A.A.M.; Hasimuna, O.J.; Abdel-Tawwab, M.; Khalil, H.S. Impacts of water additives on water quality, production efficiency, intestinal morphology, gut microbiota, and immunological responses of Nile tilapia fingerlings under a zero-water-exchange system. Aquaculture 2022, 547, 737503. [CrossRef]

50. López-Olmeda, J.F.; Noble, C.; Sánchez-Vázquez, F.J. Does feeding time affect fish welfare? Fish Physiol. Biochem. 2012, 38 , 143-152. [CrossRef]

51. Xie, M.; Zhou, W.; Xie, Y.; Li, Y.; Zhang, Z.; Yang, Y.; Olsen, R.E.; Ran, C.; Zhou, Z. Effects of Cetobacterium somerae fermentation product on gut and liver health of common carp (Cyprinus carpio) fed diet supplemented with ultra-micro ground mixed plant proteins. Aquaculture 2021, 543, 736943. [CrossRef]

52. Ostaszewska, T.; Dabrowski, K.; Kamaszewski, M.; Grochowski, P.; Verri, T.; Rzepkowska, M.; Wolnicki, J. The effect of plant protein-based diet supplemented with dipeptide or free amino acids on digestive tract morphology and PepT1 and PepT2 expressions in common carp (Cyprinus carpio L.). Comp. Biochem. Physiol. Part A Mol. Integr. Physiol. 2010, 157, 158-169. [CrossRef] [PubMed]

53. Øverland, M.; Sørensen, M.; Storebakken, T.; Penn, M.; Krogdahl, Å.; Skrede, A. Pea protein concentrate substituting fish meal or soybean meal in diets for Atlantic salmon (Salmo salar)—Effect on growth performance, nutrient digestibility, carcass composition, gut health, and physical feed quality. Aquaculture 2009, 288, 305-311. [CrossRef]

54. Roh, H.; Park, J.; Kim, A.; Kim, N.; Lee, Y.; Kim, B.S.; Vijayan, J.; Lee, M.K.; Park, C.-I.; Kim, D.-H. Overfeeding-Induced Obesity Could Cause Potential Immuno-Physiological Disorders in Rainbow Trout (Oncorhynchus mykiss). Animals 2020, 10, 1499. [CrossRef] [PubMed]

55. Butt, R.L.; Volkoff, H. Gut Microbiota and Energy Homeostasis in Fish. Front. Endocrinol. 2019, 10, 9. [CrossRef]

56. Serna-Duque, J.A.; Esteban, M. Effects of inflammation and/or infection on the neuroendocrine control of fish intestinal motility: A review. Fish Shellfish. Immunol. 2020, 103, 342-356. [CrossRef] [PubMed]

57. Udayangani, R.; Dananjaya, S.; Nikapitiya, C.; Heo, G.-J.; Lee, J.; De Zoysa, M. Metagenomics analysis of gut microbiota and immune modulation in zebrafish (Danio rerio) fed chitosan silver nanocomposites. Fish Shellfish. Immunol. 2017, 66, 173-184. [CrossRef]

58. Azimirad, M.; Meshkini, S.; Ahmadifard, N.; Hoseinifar, S.H. The effects of feeding with synbiotic (Pediococcus acidilactici and fructooligosaccharide) enriched adult Artemia on skin mucus immune responses, stress resistance, intestinal microbiota and performance of angelfish (Pterophyllum scalare). Fish Shellfish. Immunol. 2016, 54, 516-522. [CrossRef] [PubMed] 
59. Segner, H.; Sundh, H.; Buchmann, K.; Douxfils, J.; Sundell, K.S.; Mathieu, C.; Ruane, N.; Jutfelt, F.; Toften, H.; Vaughan, L. Health of farmed fish: Its relation to fish welfare and its utility as welfare indicator. Fish Physiol. Biochem. 2012, 38, 85-105. [CrossRef]

60. Sealey, W.M.; Conley, Z.B.; Bensley, M. Prebiotic Supplementation has Only Minimal Effects on Growth Efficiency, Intestinal Health and Disease Resistance of Westslope Cutthroat Trout Oncorhynchus clarkii lewisi Fed 30\% Soybean Meal. Front. Immunol. 2015, 6, 396. [CrossRef]

61. Zhang, Y.-L.; Duan, X.-D.; Jiang, W.-D.; Feng, L.; Wu, P.; Liu, Y.; Jiang, J.; Kuang, S.-Y.; Tang, L.; Tang, W.-N.; et al. Soybean glycinin decreased growth performance, impaired intestinal health, and amino acid absorption capacity of juvenile grass carp (Ctenopharyngodon idella). Fish Physiol. Biochem. 2019, 45, 1589-1602. [CrossRef] [PubMed]

62. Torrecillas, S.; Makol, A.; Benítez-Santana, T.; Caballero, M.J.; Montero, D.; Sweetman, J.; Izquierdo, M. Reduced gut bacterial translocation in European sea bass (Dicentrarchus labrax) fed mannan oligosaccharides (MOS). Fish Shellfish. Immunol. 2011, 30, 674-681. [CrossRef]

63. Van den Ingh, T.S.G.A.M.; Krogdahl, Å.; Olli, J.J.; Hendriks, H.G.C.J.M.; Koninkx, J.G.J.F. Effects of soybean-containing diets on the proximal and distal intestine in Atlantic salmon: A morphological study. Aquaculture 1991, 94, 297-305. [CrossRef]

64. Shafique, L.; Abdel-Latif, H.M.; Hassan, F.U.; Alagawany, M.; Naiel, M.A.; Dawood, M.A.; Yilmaz, S.; Liu, Q. The feasibility of using yellow mealworms (Tenebrio molitor): Towards a sustainable aquafeed industry. Animals 2021, 11, 811. [CrossRef] [PubMed]

65. Panteli, N.; Mastoraki, M.; Lazarina, M.; Chatzifotis, S.; Mente, E.; Kormas, K.; Antonopoulou, E. Configuration of Gut Microbiota Structure and Potential Functionality in Two Teleosts under the Influence of Dietary Insect Meals. Microorganisms 2021, 9, 699. [CrossRef]

66. Islam, S.M.; Rohani, F. Shahjahan Probiotic yeast enhances growth performance of Nile tilapia (Oreochromis niloticus) through morphological modifications of intestine. Aquac. Rep. 2021, 21, 100800. [CrossRef]

67. Kaushik, S.; Oliva-Teles, A. Effect of digestible energy on nitrogen and energy balance in rainbow trout. Aquaculture 1985, 50, 89-101. [CrossRef]

68. Jahangiri, L.; Esteban, M. Administration of Probiotics in the Water in Finfish Aquaculture Systems: A Review. Fishes 2018, 3, 33. [CrossRef]

69. Moriarty, D.J. Control of luminous Vibrio species in penaeid aquaculture ponds. Aquaculture 1998, 164, 351-358. [CrossRef]

70. Sakai, M.; Yoshida, T.; Atsuta, S.; Kobayashi, M. Enhancement of resistance to vibriosis in rainbow trout, Oncorhynchus mykiss (Walbaum), by oral administration of Clostridium butyricum bacterin. J. Fish Dis. 1995, 18, 187-190. [CrossRef]

71. Elsabagh, M.; Mohamed, R.; Moustafa, E.M.; Hamza, A.; Farrag, F.; DeCamp, O.; Dawood, M.; Eltholth, M. Assessing the impact of Bacillus strains mixture probiotic on water quality, growth performance, blood profile and intestinal morphology of Nile tilapia, Oreochromis niloticus. Aquac. Nutr. 2018, 24, 1613-1622. [CrossRef]

72. Sunitha, K.; Padmavathi, P. Influence of probiotics on water quality and fish yield in fish ponds. Int. J. Pure Appl. Sci. Technol. 2013, 19, 48.

73. Deng, Y.; Verdegem, M.C.; Eding, E.; Kokou, F. Effect of rearing systems and dietary probiotic supplementation on the growth and gut microbiota of Nile tilapia (Oreochromis niloticus) larvae. Aquaculture 2022, 546, 737297. [CrossRef]

74. Putra, D.F.; Fanni, M.; Muchlisin, Z.A.; Muhammadar, A.A. Growth performance and survival rate of climbing perch (Anabas testudineus) fed Daphnia sp. enriched with manure, coconut dregs flour and soybean meal. Aquac. Aquar. Conserv. Legis. 2016, 9, 944-948.

75. Merrifield, D.L.; Dimitroglou, A.; Foey, A.; Davies, S.J.; Baker, R.T.; Bøgwald, J.; Castex, M.; Ringø, E. The current status and future focus of probiotic and prebiotic applications for salmonids. Aquaculture 2010, 302, 1-18. [CrossRef]

76. Zibiene, G.; Zibas, A. Impact of commercial probiotics on growth parameters of European catfish (Silurus glanis) and water quality in recirculating aquaculture systems. Aquac. Int. 2019, 27, 1751-1766. [CrossRef]

77. El-Kady, A.A.; Magouz, F.I.; Mahmoud, S.A.; Abdel-Rahim, M.M. The effects of some commercial probiotics as water additive on water quality, fish performance, blood biochemical parameters, expression of growth and immune-related genes, and histology of Nile tilapia (Oreochromis niloticus). Aquaculture 2022, 546, 737249. [CrossRef]

78. Cruz, P.M.; Ibáñez, A.L.; Hermosillo, O.A.M.; Saad, H.C.R. Use of Probiotics in Aquaculture. ISRN Microbiol. 2012, 2012, 1-13 [CrossRef]

79. Jafaryan, H.; Taati, M.M.; Jafarzadeh, M. The enhancement of growth parameters in common carp (Cyprinus carpio) larvae using probiotic in rearing tanks and feeding by various Artemia nauplii. Aquac. Aquar. Conserv. Legis. 2011, 4, 511-518.

80. Morales-Jiménez, J. Effect of bacterial probiotics bio-encapsulated into Artemia franciscana on weight and length of the shortfin silverside (Chirostoma humboldtianum), and PCR-DGGE characterization of its intestinal bacterial community. Lat. Am. J. Aquat. Res. 2017, 45, 1031-1043.

81. Merrifield, D.L.; Dimitroglou, A.; Bradley, G.; Baker, R.T.M.; Davies, S.J. Probiotic applications for rainbow trout (Oncorhynchus mykiss Walbaum) I. Effects on growth performance, feed utilization, intestinal microbiota and related health criteria. Aquac Nutr. 2010, 16, 504-510. [CrossRef]

82. Begum, N.; Islam, M.; Haque, A.; Suravi, I. Growth and yield of monosex tilapia Oreochromis niloticus in floating cages fed commercial diet supplemented with probiotics in freshwater pond, Sylhet. Bangladesh J. Zool. 2017, 45, 27-36. [CrossRef]

83. Gong, W.; Gao, S.; Zhu, Y.; Wang, G.; Zhang, K.; Li, Z.; Yu, E.; Tian, J.; Xia, Y.; Xie, J.; et al. Effect of the Aerobic Denitrifying Bacterium Pseudomonas furukawaii ZS1 on Microbiota Compositions in Grass Carp Culture Water. Water 2021, 13, 1329. [CrossRef] 
84. Tang, J.-Y.; Dai, Y.-X.; Li, Y.-M.; Qin, J.-G.; Wang, Y. Can Application of Commercial Microbial Products Improve Fish Growth and Water Quality in Freshwater Polyculture? N. Am. J. Aquac. 2016, 78, 154-160. [CrossRef]

85. Thurlow, C.M.; Williams, M.A.; Carrias, A.; Ran, C.; Newman, M.; Tweedie, J.; Allison, E.; Jescovitch, L.N.; Wilson, A.E.; Terhune, J.S.; et al. Bacillus velezensis AP193 exerts probiotic effects in channel catfish (Ictalurus punctatus) and reduces aquaculture pond eutrophication. Aquaculture 2019, 503, 347-356. [CrossRef]

86. Sharma, G.K.; Thakur, A. Bioremediation of Farm Ponds for Improving Water Quality and Fish Productivity in Bastar Plateau. Adv. Biores 2018, 9, 81-85.

87. Iribarren, D.; Dagá, P.; Moreira, M.T.; Feijoo, G. Potential environmental effects of probiotics used in aquaculture. Aquac. Int. 2012, 20, 779-789. [CrossRef] 